University of South Florida

DIGITAL COMMONS

Digital Commons @ University of

@ UNIVERSITY OF SOUTH FLORIDA

South Florida

$1-2005$

\title{
The Public Library as a Public Forum: The (DE)evolution of a Legal Doctrine
}

John N. Gathegi

Florida State University, jgathegi@usf.edu

Follow this and additional works at: https://digitalcommons.usf.edu/si_facpub

Part of the Law Commons, and the Library and Information Science Commons

\section{Scholar Commons Citation}

Gathegi, John N., "The Public Library as a Public Forum: The (DE)evolution of a Legal Doctrine" (2005). School of Information Faculty Publications. 297.

https://digitalcommons.usf.edu/si_facpub/297

This Article is brought to you for free and open access by the School of Information at Digital Commons @ University of South Florida. It has been accepted for inclusion in School of Information Faculty Publications by an authorized administrator of Digital Commons @ University of South Florida. For more information, please contact digitalcommons@usf.edu. 
The Public Library as a Public Forum: The (De)Evolution of a Legal Doctrine Author(s): John N. Gathegi

Source: The Library Quarterly: Information, Community, Policy, Vol. 75, No. 1 (January 2005), pp. 1-19

Published by: University of Chicago Press

Stable URL: http://www.jstor.org/stable/10.1086/428690

Accessed: 21-12-2015 16:35 UTC

Your use of the JSTOR archive indicates your acceptance of the Terms \& Conditions of Use, available at http://www.jstor.org/page/ info/about/policies/terms.jsp

JSTOR is a not-for-profit service that helps scholars, researchers, and students discover, use, and build upon a wide range of content in a trusted digital archive. We use information technology and tools to increase productivity and facilitate new forms of scholarship. For more information about JSTOR, please contact support@jstor.org. 


\title{
THE LIBRARY QUARTERLY
}

\begin{tabular}{lll}
\hline Volume 75 & JANUARY 2005 & Number 1 \\
\hline
\end{tabular}

\section{THE PUBLIC LIBRARY AS A PUBLIC FORUM: THE (DE)EVOLUTION OF A LEGAL DOCTRINE}

\author{
John N. Gathegi ${ }^{1}$
}

\begin{abstract}
When dealing with First Amendment free speech issues in the context of public libraries, courts have merely cited the supposition that constitutional public forum analysis leads to the conclusion that the public library is a limited public forum for the purposes of First Amendment analysis. By focusing narrowly on the issue of whether Internet access in libraries constitutes a public forum, and determining that it does not, the U.S. Supreme Court not only misses an opportunity to refine the concept of the public forum in modern-day terms but also somehow implies that public library activities are different from other speech activities and are subject to the managerial authority of the government. This article makes the argument that a redefinition of the public forum doctrine would bring under its ambit the public library, to join the "traditional" public forums such as streets, sidewalks, and parks-a departure from the current designation of the public library as a limited public forum. This article also examines the extent to which the Internet represents an expansion of the forum, whether public or limited. The argument is structured within the framework of the decision in the case of United States v. American Library Association.
\end{abstract}

\section{Introduction}

In its 2003 decision in United States v. American Library Association, the U.S. Supreme Court squandered an opportunity to define analytically what kind

1. Associate professor, School of Information Studies, Florida State University, 238 Louis Shores Building, Tallahassee, FL 32306-2100. Telephone 850-644-8104; Fax 850-644-6253; E-mail jgathegi@lis.fsu.edu.

\author{
[Library Quarterly, vol. 75, no. 1, pp. 1-19] \\ (C) 2005 by The University of Chicago. All rights reserved. \\ 0024-2519/2005/7501-0001\$10.00
}


of forum a public library is [1]. ${ }^{2}$ When dealing with First Amendment free speech issues in the context of public libraries, courts have merely cited the supposition that constitutional public forum analysis leads to the conclusion that, for the purposes of First Amendment analysis, the public library is a limited public forum. ${ }^{3}$ By focusing narrowly on the issue of whether Internet access in libraries constitutes a public forum, and determining that it does not, the Court not only misses an opportunity to refine the concept of the public forum in modern-day terms but also somehow implies that public library activities are different from other speech activities and are subject to the managerial authority of the government. ${ }^{4}$

This article rejects the conclusionary views of the courts of the status of the public library as a limited forum, arguing instead that a redefinition of the public forum doctrine would bring under its ambit the public library to join the "traditional" public forums such as streets, sidewalks, and parks. ${ }^{5}$ This article further subscribes to the view that a traditional forum analysis is inappropriate and stultifying and that a compatibility test, while not by itself optimal, yields the more plausible analytical results.

Why, one might ask, does it matter what type of forum a public library is characterized as? A partial answer, as we shall see below, emerges from the fact that such a characterization determines the different levels for review of regulations that constrain speech. ${ }^{6}$ In a public forum, regulation of speech is examined under strict scrutiny, while regulation of speech in government property that is not a traditional public forum is examined

2. United States v. American Library Association was a case reviewing the constitutionality of the Childrens' Internet Protection Act (CIPA) on a facial validity challenge. Most of the legal and nonlegal commentary on this case has focused on the vagueness and overbreadth arguments made in the lower court, while ignoring two major important points: the Court's focus on whether or not access to the Internet opened up a public forum and whether or not a spending clause analysis applies to this forum.

3. See, e.g., [2-4]. Both Kreimer v. Bureau of Police for the Town of Morristown and Mainstream Loudoun $v$. Board of Trustees of Library carefully examined the forum nature of the public library and, using the Court's classic forum analysis, came to the conclusion that the public library is a limited public forum. It is this classical analysis that this article challenges.

4. While there are differences in the meanings of the Internet and the World Wide Web (the Web), I shall, in this article, use the two terms interchangeably.

5. Public forums may be favorably compared to the "public spheres" of deliberation that Jurgen Habermas described as emerging in the eighteenth century, though the latter were developed by the bourgeoisie. While I believe an examination of the concept of "public spheres" would uncover unmistakable alignment to the concept of public forums, that examination is outside the scope of the present discussion and will have to be carried out separately in another work [5].

6. "Consideration of a forum's special attributes is relevant to the constitutionality of a regulation since the significance of the governmental interest must be assessed in light of the characteristic nature and function of the particular forum involved." See [6, p. 732]. 
only for reasonableness [6]. I shall discuss below the significance of the different levels of review.

The rest of this article is structured in five major parts. In Sections II and III, I review public forum doctrine by discussing the two major constitutionally recognized fora: the traditional public forums and the designated or limited public forums. ${ }^{7}$ I ignore nonpublic forums because they are generally outside of forum analysis, unless they have been opened up to some sort of expressive activity. In Section IV, I examine the public library in the context of public forum doctrine, specifically discussing the question of what type of a forum it is. I do this by reviewing forum analysis as applied to public libraries by the courts and by demonstrating that this analysis has been flawed, or needs modification. Section V critically examines the status quo of the public library in the context of constitutional forum analysis after United States v. American Library Association. I offer my conclusions in Section VI, arguing that the public library should assume its seat in the quintessential traditional public forums, if we must use that analysis, or that, alternatively, we should redefine what a public forum is and ensure that the public library fit in that definition.

\section{Traditional Public Forums}

Traditional public forum doctrine recognizes places like streets, parks, and sidewalks as comprising quintessential public forums. Curiously, despite its anchor in government property, this doctrine was born out of private property ownership, typified by the Court's firmness on "the right of owners of private property to prevent others from using their property for speech purposes" because it "would be an unwarranted infringement of property rights to require them to yield to the exercise of First Amendment rights" [7].

But if state property is also public property, how can we use private property notions to define public forums? The 1897 case of Commonwealth of Massachusetts $v$. Davis [8] attempted to solve the public forum problem by appealing to common law private property concepts. In a state supreme court ruling by Justice Holmes, later confirmed by the U.S. Supreme Court (under Chief Justice White), the fact that the legislature had the power to end the right of the public to enter a public space meant that it could also limit the public use to certain purposes. Later U.S. Supreme Court First Amendment doctrine refined this approach severely. In 1939, Justice

7. Occasionally, the courts will use the word "fora" as the plural of "forum." However, the typical usage is "forums," which I will henceforth follow. 
Roberts, implicitly accepting the Holmes-White approach, appeared to create "a kind of First-Amendment easement" [9, p. 13]. Those public places that had been traditionally used for free speech purposes could continue to be so used, but the state was free to regulate other property that had not been traditionally so used.

Thus, the Court's public forum analysis has its origins in Justice Robert's dictum in Hague v. CIO:

Wherever the title of streets and parks may rest, they have immemorially been held in trust for the use of the public and, time out of mind, have been used for purposes of assembly, communicating thought between citizens, and discussing public questions. Such use of the streets and public places has, from ancient times, been a part of the privileges, immunities, rights, and liberties of citizens. The privilege of a citizen of the United States to use the streets and parks for communication of views on national questions may be regulated in the interest of all; it is not absolute, but relative, and must be exercised in subordination to the general comfort and convenience, and in consonance with peace and good order; but it must not, in the guise of regulation, be abridged or denied. [10, pp. 515-16]

In the same year (1939), in Schneider v. State [11], the Court held that a city's interest in maintaining "the streets clean and of good appearance" was "insufficient" to defend a city ordinance that prohibited leaflet distribution on public property. Jamison v. Texas [12] followed suit by invalidating another city ordinance that prohibited leaflet dissemination. This view of the street as a public forum was reinforced in United States v. Grace [13], in which the Supreme Court invalidated a federal statute that prohibited the display of "any flag, banner, or device designed to bring into public notice any party, organization or movement" on sidewalks surrounding the Supreme Court. The Court recognized public sidewalks to be a public forum where restriction of public expression could only be limited by content-neutral, reasonable time, place, and manner regulations. In this particular case, the Court held that the restrictions were not reasonable, as a total ban of the expressive activities was not necessary to "maintain proper order and decorum" near the Supreme Court. Following Justice Robert's dictum, the Grace Court reaffirmed that streets, sidewalks, parks, and such "public places" historically associated with the free exercise of expressive activities "are considered, without more, to be "public forums"' [13, p. 177].

However, the Court in Grayned v. Rockford [14] upheld the conviction of a demonstrator involved in a march protesting a public high school's racial policies that was held on a public sidewalk near the school. Here, the Court elucidated that, even though the public sidewalk from the high school could not be declared off limits to expressive activity, such activity may be prohibited if it materially disrupts class work or invades the rights of others. The crucial question, the Court said, "is whether the manner of expression 
is basically incompatible with the normal activity of a particular place at a particular time" [14, p. 116].

Thus, following this logic, the Court in Boos v. Barry [15] was able to uphold a District of Columbia code that made it illegal to disobey a police order to disperse from an assembly of people within 500 feet of a foreign embassy when the embassy's security or peace was reasonably believed to be under threat. Similarly, the Court in Frisby v. Shultz [16] let stand a town ordinance that prohibited residential picketing that focuses on a particular residence-in this case, the residence of a doctor who performed abortions. The Court felt the ordinance was constitutional because it was narrowly tailored to serve a significant government interest and left the door open for other alternative channels of communication. The Court, as in Lloyd Corporation v. Tanner, appeared here to pay homage to the sanctity of a man's home and to balance residential privacy against the elevated status of the street as a public forum.

In Clark v. Community for Creative Non-Violence [17], the Court upheld a National Park Service regulation prohibiting sleeping overnight in tent cities it had allowed to be erected in a park for the purposes of demonstrating the plight of the homeless. Here, even though the park was considered a public forum, and the tent cities symbolic speech, the Court found the no overnight sleeping regulation was a reasonable time, place, and manner restriction to limit the "size and duration" of similar demonstrations. Similarly, a New York City regulation mandating the use of city-provided technicians and sound systems for concerts in Central Park was found to be a reasonable time, place, and manner restriction, because the restrictions were "justified without reference to the content of the regulated speech, that they [were] narrowly tailored to serve a significant government interest" in protecting the city's citizens from unwelcome noise, despite the fact that the regulations were not the least intrusive means of doing so, and because they "[left] open ample channels for communication of the information" [18, p. 802].

In 1966, when affirming the conviction on trespass charges of some Florida A \& M students who had gone to a jailhouse entrance to protest the arrest of their schoolmates who had been engaged in a civil rights demonstration that tried to integrate public theaters, the Court, again invoking notions of private property ownership, stated that "the State, no less than a private owner of property, has the power to preserve the property under its control for the use to which it is lawfully dedicated" [19].

Thus, it appears that there are sidewalks, and then there are sidewalksthat is, not all sidewalks open to the public are public forums. In United States $v$. Kokinda [6], the Court distinguished between a postal sidewalk and a regular sidewalk. The former "was constructed solely to provide for the passage of individuals engaged in postal business" and does not "have 
the characteristics of public sidewalks traditionally open to expressive activity" [19, p. 727].

Here then, we start to see the beginnings of a concern with the function of the property, when the property involved is not a traditional public forum or has some other specialized function. An opportunity to extend the inquiry arose in a most unlikely place: airport terminals. The question of whether airport terminals are public forums had dogged the courts for a while, with splits among the circuit courts, the majority holding the view that the public spaces in airports are public forums. ${ }^{8}$ International Society for Krishna Consciousness $v$. Lee [25] provided an opportunity to resolve the question.

The case is remarkable, not for its clarity in resolving the issue but in its analysis of the various categories of forums. The Krishna Court determined that an airport terminal is not a public forum for First Amendment purposes, and, thus, a ban on solicitation need only satisfy a reasonableness standard [25]. But in a companion decision regarding the constitutionality of banning distribution of literature in airport terminals, such a ban on leafleting, as opposed to soliciting, was held invalid [26].

The Krishna Court, in terms reminiscent of Robert Post's theory of managerial authority (discussed below), distinguished the regulation of speech where the government is acting as a manager from similar regulation where it is acting as a governor. Rules regulating speech are different in managerial authority than in governance. As in Kokinda, "where the government is acting as a proprietor, managing its internal operations rather than acting as lawmaker with the power to regulate or license, its action will not be subjected to heightened review to which its actions as a lawmaker may be subject" [25, pp. 2705-6]. Thus, we see the Krishna Court's criteria for identifying a public forum: (1) tradition and (2) purpose [25, p. 2704]. The Krishna Court, drawing from Perry Education Association v. Perry Local Educators' Association [27], also delineated three categories of public property and their correspondent degree of "public fora," what it called a "forum-based" approach.

In this section, I have discussed the first kind of forum: the public forum. Below, I shall examine the other forum categories that do not fall under this rubric. To recapitulate, content-based speech regulations in a public forum are proscribed. To survive strict scrutiny, such regulations must serve a compelling state interest and must be narrowly drawn to achieve that end. Reasonable, content-neutral time, place, or manner restrictions are, however, permitted [28].

8. See, e.g., [20-24]. 


\section{Designated Public Forums (and Limited Public Forums)}

The designated forum is hewn out of the government property that is not a traditional public forum but in which expressive activity is nevertheless allowed. This property generally does not satisfy public forum criteria, but the government reserves power to dedicate the property for all or limited speech. The government does this "by intentionally opening a nontraditional forum for discourse" [25, p. 2706]. Here, unlike in the protected public forum above, the government often restricts speech to retain the designated property's purpose. Also, the government may choose to eliminate the speech-dedication designation of such property [26, pp. 2718-19] because, according to Greer, "the government does not create a public forum by inaction. Nor is a public forum created 'whenever members of the public are permitted freely to visit a place owned or operated by the Government"' [29]. However, once created, designated public forums afford the same level of protection from regulation of speech as the public forums do. As in the public forums, valid time, place, and manner regulations are allowed. To be valid, however, the regulations must (1) be content neutral, (2) be designed to serve significant government interests, including public health and safety, and (3) leave ample alternative channels for expressive activity.

Whether a forum is viewed as a designated or limited public forum is determined on a case-by-case basis. Both Kreimer and Mainstream Loudoun, for example, looked at (1) whether or not the government intended to designate a facility as a public forum, (2) the extent of the use the government has allowed in the facility, and (3) whether the nature of the forum is compatible with expressive activity.

Because nonpublic forums are not the focus of this article, I shall make only a fleeting reference to them. As I have discussed above, government regulations that constrain speech, both in a traditional or a designated public forum, will be examined under strict scrutiny. Such restrictions in nonpublic forums, however, will only be reviewed for reasonableness [6].

For nonpublic forums, the reasonableness requirement is easily surmountable: a restricting regulation need not be the most reasonable or the only reasonable limitation; it need only be reasonable $[6$, p. 3124; 30, p. 808]. Reasonableness will "be assessed in light of the purpose of the forum and all the surrounding circumstances" [30, p. 809]. The relationships between the three forum categories I have discussed above are illustrated in table 1 . 
TABLE 1

Framework for a Forum-Based Approach to Public Forums

\begin{tabular}{|c|c|c|c|}
\hline Category & Description & Level of Review & $\begin{array}{c}\text { Nature and Effect of } \\
\text { Review }\end{array}$ \\
\hline \multirow[t]{2}{*}{ Public forum } & $\begin{array}{l}\text { Government property } \\
\text { that has tradition- } \\
\text { ally been available } \\
\text { for public expres- } \\
\text { sion (e.g., streets, } \\
\text { sidewalks, parks) }\end{array}$ & Highest (strict) scrutiny & $\begin{array}{l}\text { Regulations survive } \\
\text { only if they are nar- } \\
\text { rowly drawn to } \\
\text { achieve a compelling } \\
\text { state interest }\end{array}$ \\
\hline & & $\begin{array}{l}\text { Content-neutral time, } \\
\text { place, and manner } \\
\text { regulations allowed }\end{array}$ & Upheld if reasonable \\
\hline $\begin{array}{l}\text { Designated } \\
\text { or lim- } \\
\text { ited pub- } \\
\text { lic fo- } \\
\text { rum: }\end{array}$ & $\begin{array}{l}\text { Property that the state } \\
\text { has opened for ex- } \\
\text { pressive activity by: }\end{array}$ & $\begin{array}{l}\text { Regulation of such } \\
\text { property subject to } \\
\text { the same limitations } \\
\text { as that governing a } \\
\text { traditional public } \\
\text { forum }\end{array}$ & $\begin{array}{l}\text { Government retains } \\
\text { the power to dedi- } \\
\text { cate its property for } \\
\text { speech, either for } \\
\text { full or limited } \\
\text { expression }\end{array}$ \\
\hline $\begin{array}{l}\text { Unlimited } \\
\text { Limited }\end{array}$ & $\begin{array}{l}\text { All of the public } \\
\text { Part of the public }\end{array}$ & & \\
\hline $\begin{array}{r}\text { Nonpublic } \\
\text { forum }\end{array}$ & $\begin{array}{c}\text { All other public } \\
\text { property }\end{array}$ & $\begin{array}{l}\text { Limited review for rea- } \\
\text { sonableness as long } \\
\text { as no attempt to sup- } \\
\text { press because of dis- } \\
\text { agreement with } \\
\text { speaker's view }\end{array}$ & $\begin{array}{l}\text { Limitations on expres- } \\
\text { sive activity need } \\
\text { only survive a much } \\
\text { more limited review }\end{array}$ \\
\hline
\end{tabular}

IV. The Public Library: What Forum?

What kind of forum is a public library? Is it a public forum, or a designated/ limited one? Why does it matter what type of forum a public library is characterized as being? The question is significant because, as discussed above, the answer determines the analysis and the level of review of regulations constraining speech.

A series of cases that have considered this question have all concluded, without much analysis, that the public library is not a traditional public forum. According to the courts, the public library is, for the purposes of First Amendment analysis, a limited public forum, even though they acknowledge the status of the library as the "quintessential locus of the receipt of information" and recognize the right to receive information..$^{9}$ One court

9. See, e.g., [2; 3, p. 1259], and [4, p. 563]. Interestingly, while insisting that the public library is only a limited forum, the courts nevertheless seem to have embraced two important 
even went further to declare that even though the library was "not a traditional public forum, the library's practice of allowing use of its auditorium by groups unrelated to the library's mission had created a public forum" [33]. Thus, I am perfectly willing to recognize public forums within spaces in the public library, but I am only willing to accord the status of a limited public forum to the public library itself. Public libraries, it would seem, simply do not fit into the categories of streets, sidewalks and parks that have "time out of mind . . . been used for the purposes of assembly, communication of thoughts between citizens, and discussing public questions" [10, p. 515].

A case involving denial of patron's access to the library based on his failure to wear shoes is illustrative of the courts' forum analysis of public libraries [2]. The Court in Neinast begins by declaring that, for the purposes of First Amendment analysis, a library is a limited public forum. As a limited public forum, therefore, it is only required to allow the exercise of those rights by the public that are consistent with the nature of a library and the government's purpose in designating the library as a public forum [2]. However, because the issue in dispute went to the library's interest in protecting public health, the Court did not go into a discussion of what the nature of a library is and what the government's purpose is in characterizing it as a designated public forum. The closest the courts have come to such a discussion was in describing libraries as traditionally providing a place for "reading, writing, and quiet contemplation" [3].

In discussing limited public forums, both Kreimer and Mainstream Loudoun employ forum analysis to review library policies and regulations. Kreimer, on the one hand, involved a homeless man who was a frequent visitor to the public library of Morristown, New Jersey. The library expelled him five times on the grounds that he violated library policy on patron conduct by, among other things, talking loudly to himself, staring and following other users, and having an offensive body odor. Mainstream Loudoun, on the other hand, involved a challenge to a library's policy of limiting access to certain content on the Internet, which it implemented by installing site-blocking software. Both cases involved the First Amendment. Even though Kreimer upheld the library's policy while Mainstream Loudoun invalidated it, both cases concluded, as we shall see below, that the public library is a designated or limited public forum-Kreimer because the public library was dissimilar to traditional public forums and Mainstream Loudoun because Kreimer said so.

As I shall discuss below, this failure by the courts in analyzing the nature

American Library Association documents: the Library Bill of Rights and the Intellectual Freedom Manual. The courts have described public libraries as "designed for freewheeling inquiry"; see [31]. A public library is "the quintessential locus of the receipt of information"; see [3, p. 1255]. A library is a "mighty resource in the free marketplace of ideas"; see [32, p. 582]. 
of a public library has left the library miscategorized as a limited public forum and has resulted in the courts narrowly drawing the contours of that forum within the library itself.

The conclusion that the public library is a limited public forum derives from the notion of a building (private property) owned by the government. But what are we to make of the observation that members of the public are allowed to freely enter and leave the library when it is open and that this a place to have access to information, the essential stuff of First Amendment concerns? The Court in Greer v. Spock, reaching to the concept of the state as a property owner, rejected "the principle that whenever members of the public are permitted freely to visit a place owned or operated by the government, then that place becomes a 'public forum' for purposes of the First Amendment" [29; 34]. But the context here was within a military base training soldiers and not a building providing reading material and other access to information. But, has the government intentionally opened the library, a "nontraditional forum" for public discourse? The courts have admitted as much. The crucial question goes to the extent of this opening-whether, as I argue below, it has created, rather than a limited public forum, a full-fledged public forum of the same stature as streets, sidewalks, and parks.

Is there, then, any historical or constitutional support for the characterization of the public library as a public forum? As I discussed above, streets, parks, and sidewalks gained their public forum status simply by being used as such. But the courts seem to have closed off membership in that category to only the existing members. ${ }^{10}$ I propose to open up this category to new membership and plant the public library firmly within it.

I begin by examining the "special attributes" and "surrounding circumstances" of public libraries. Public libraries are probably one of the very few government institutions that government has funded and provided free to members of the public, wholly for the enjoyment of the public, without expecting accountability for the benefit of being able to access information. Government has done this in the belief that an informed citizenry is essential for the functioning of democracy. The public library, like the street, the sidewalk, and the park, is an essential component of the marketplace of ideas. As in the streets, members of the public have open ingress and egress; they meet to exchange information, among other activities. Certain areas in the library may not be accessible to the public; but similarly, certain areas of the street, such as manholes and maintenance areas, are restricted from members of the public.

10. This is reminiscent of the Security Council permanent membership at the United Nations in which only the original five member countries are permanent members, with the exception of Russia, which took the former USSR seat. The other ten members are elected. 
I reach back to Grayned, not to the decisional analysis, but to the dictum's analysis of the issue of public forums. When determining the kinds of regulations of time, place, and manner that are reasonable, we look at the nature of a place and "the pattern of its normal activities" to see "whether the manner of expression is basically incompatible with the normal activity of a particular place at a particular time" $[14$, p. 116]. Stone notes that

In [the Grayned dictum], the right to a public forum came of age. No longer does the right to effective freedom of expression turn on the common law property rights of the state, and no longer does it turn on whether the particular place at issue has historically been dedicated to the exercise of First Amendment rights. The streets, parks, public libraries, and other publicly owned places are all brought under the same roof. In each case, the "crucial question is whether the manner of expression is basically incompatible with the normal activity of a particular place at a particular time." [35, pp. 251-52]

I subscribe to the notion, therefore, that the definition of a traditional public forum merely by appeal to its historical uses as such, and the restriction of membership to three or so enumerated members (streets, sidewalks, and parks), is flawed. The normal activity of a public library is access and dissemination of information.

V. Regression: View of the Public Library as a Public Forum after United States v. American Library Association

In United States v. American Library Association, the U.S. Supreme Court (the $A L A$ Court) reviewed the constitutionality of the Children's Internet Protection Act (CIPA), which was challenged on its facial validity by a group of libraries, users, and Web site publishers. CIPA was designed to protect children from accessing sexual content through the Internet in the public library by requiring libraries that received certain federal funding for connectivity and Internet access to install filters in their network computers. ${ }^{11}$ The Court ruled CIPA constitutional because it was not in violation of the free speech clause of the First Amendment, nor did it impose an impermissible condition on public libraries. The Court concluded that the federal assistance to libraries was meant to assist the libraries in its traditional role of obtaining appropriate educational and informational material, and Congress could demand that the funds be used only for that purpose. It also concluded that Internet access in public libraries did not create either a public forum or a designated one [1, p. 204].

11. The Telecommunications Act e-rates program and Library Services and Technology Act (LSTA) grants. 
Accessing information from both the shelves and the computers in the library is, despite the $A L A$ Court's conclusion, quite compatible with the library's normal activity. Contrary to the $A L A$ Court's view, the public library implements a collection development policy not because of its desire to censor, but because it cannot afford to buy everything, and also because not everything is appropriate for its collection. Pages from the accounting book of the local church, for example, might not be appropriate unless the library has a local history collection. On the Internet, cost of the material is not a factor. the ALA Court seemed to adopt the patronizing view held by the nobility for commoners: we know what is best for you.

Perhaps one of the reasons for the reluctance of courts to recognize public libraries as full-fledged public forums has been the speaker/receiver dichotomy. In the traditional forums, our main interest is protecting the speaker; we already assume the public has a right to hear the speaker. The problem then becomes that we are not concerned with protecting the speaker in a public library. Indeed, users have to suppress a fair amount of speech in order for the library to carry out its mission. But suppression of speech is also common in streets and parks; otherwise, the usefulness of those venues for transportation and recreation would permanently be undermined if demonstrations occurred every day and night of the year. Thus, that speakers are restrained in the range of their speech does not detract from the public forum nature of the traditional forums.

As we have seen above, when dealing with First Amendment free speech issues in the context of public libraries, courts have merely cited the supposition that constitutional public forum analysis leads to the conclusion that the public library is a limited public forum. In its 2003 decision in United States v. American Library Association, the U.S. Supreme Court was presented, for the first time, with an opportunity to analytically define what kind of forum a public library is. But, by focusing narrowly on the issue of whether Internet access in libraries constitutes a public forum and determining that it does not, the Court not only missed an opportunity to refine the concept of the public forum in modern-day terms but also somehow implied that public library activities are different from other speech activities and are subject to the managerial authority of the government.

By framing the issue in this manner, the Court needed only view filters as time, place, and manner regulations, somehow overlooking the requirement that such regulations be content neutral. In any case, the Court seemed determined to reach a decision based on the Congress spending power clause, which fit rather nicely with the concept of managerial authority.

The Krishna Court defined public forums as limited to that public prop- 
erty which has as "a principal purpose . . . the free exchange of ideas . . . this purpose must be evidenced by a long-standing historical practice of permitting speech" [26, pp. 2711-12]. Clearly, public libraries would fall under the category of public property that exists to facilitate the free exchange of ideas. Applying this view of public libraries would have allowed the Court to veer away from the antiquated doctrine of the quintessential public forums limited to streets, parks, and sidewalks.

In his concurrence in Krishna, Kennedy describes as fiction that these particular places have public discourse as their principal purpose [26, $\mathrm{p}$. 2717]. According to Kennedy, streets and sidewalks exist to facilitate transportation, while parks arguably are to provide beauty and open space. Limiting the doctrine of public forums to these specific places "leaves almost no scope for the development of new public forums absent the rare approval of the government" [26, p. 2716]. Kennedy pointed out the same error that the $A L A$ Court appears to commit: the "conclusion that the public-forum status of public property depends on the government's defined purpose for the property or on an explicit decision by the government to dedicate the property to expressive activity" [26, p. 2716]. Kennedy was of the view that a public forum analysis "must be an objective one, based on the actual, physical characteristics and uses of the property" [26, p. 2716] rather than on a historical determination. In our view, this would permit the recognition of new public forums that would include the public library.

The ALA Court should have shared Kennedy's concern that failure to recognize new forums will mean that "our forum doctrine retains no relevance in times of fast-changing technology and increasing insularity . . . our public forum doctrine must . . . allow the creation of public forums which do not fit within the narrow tradition of streets, sidewalks, and parks. We have allowed flexibility in our doctrine to meet changing technologies in other areas of constitutional interpretation, . . . and I believe we must do the same with the First Amendment" [26, p. 2717].

From this perspective, the ALA Court's failure to take up this challenge is a disappointment. It leaves the public library forum analysis in a worse position than it was before Grayned. As Justice Souter pointed out in his dissent: "Public forum analysis is stultified not only by treating its archetypes as closed categories, but by treating its candidates so categorically as to defeat their identification with the archetypes" [26, pp. 2711, 2724].

If the ALA Court had followed Kennedy's analysis, we would "accord public forum status to other forms of property, regardless of its ancient or contemporary origins and whether or not it fits within a narrow historic tradition." This would permit us to look at public libraries from a purpose point of view: "If the objective, physical characteristics of the property at 
issue and the actual public access and uses that have been permitted by the government indicate that expressive activity would be appropriate and compatible with those uses, the property is a public forum" [26, p. 2718].

I would argue that if the Court is persistent in its traditional public forum analysis, then the public library should assume its seat in the quintessential traditional public forums. The public library would be included among those types of government properties that have "by history and tradition been available for speech activity" [26, p. 2718]. Alternatively, we should, as the $A L A$ Court should have done, redefine what a public forum is and make sure the public library fits in. ${ }^{12}$ In any case, it is interesting to note that while the courts characterize the public library as a designated forum, the public library can be said to open a public forum when it allows groups to use its auditorium.

The Court fails to distinguish public libraries from classrooms and school libraries and seems to apply an analysis of the latter two to public libraries. The Court seems to be equating the rights of adults in a public library to the rights of students in schools and public libraries. The spending power clause might apply here. However, while the government is not obligated to subsidize the exercise of fundamental rights, including speech rights [36], CIPA is not only not subsidizing but is interfering with the exercise of a right. Even though the government may elect not to subsidize speech, CIPA helps to subsidize some speech and not others, and this is discriminatory. This discrimination is especially the kind targeted by First Amendment doctrine, as it discriminates on the basis of the viewpoint of the speech involved, a pure example of a "law . . . abridging the freedom of speech, or of the press" [37, pp. 383-84].

Contemporary public forum doctrine that the Court in $A L A$ is allowing to continue focuses on the kind of government property at issue and the historical First Amendment treatment of such property, whether or not the exercise of First Amendment rights is compatible with the nature of the property [38, p. 1766]. But even this approach puts the public library within the public forum ambit, because First Amendment rights have historically been the mainstay of public libraries.

The Court's treatment of public libraries can only be understood within Post's theory of managerial authority. Post pointed to "two kinds of government authority" in "dealing with the internal management of speech, . . . management and governance, each controlled by distinct kinds of first amendment rules" [38, p. 1776]. When the environment has been described as a public forum, then government's authority over that environment can be viewed as a matter of governance, while the same authority

12. The district court in $A L A$ came closest to correctly characterizing the public forum nature of public libraries, although it also confined itself to Internet access. 
in a nonpublic forum would be described as managerial authority [38, p. 1776]. Governance invites a higher scrutiny of speech restricting regulations than does managerial authority in which the government can internally regulate speech.

On the premise that the library is the government's own institution, the government then would view CIPA as a regulation "necessary in order to achieve the institution's legitimate objectives," to achieve what Post calls, "managerial authority over speech" [38, p. 1769]. This raises the question of whether First Amendment rights can be so radically devalued on receipt of federal funds. This is especially poignant given the fact that the libraries did not need the Court's help in upholding their managerial authority, as demonstrated by the fact that their premier association took the plaintiff's role on their behalf.

In United States v. Playboy, the Court ruled that the Telecommunications Act's "signal bleed" provision that required cable operators to scramble or limit programming to certain hours was a content regulation, because the regulation was not concerned with signal bleed from other types of channels, only those with sexually oriented programming [39]. The Children's Internet Protection Act is comparable in its focus on filtering sexually oriented material and especially attracts our attention because it occurs in a public forum environment, whether traditional or designated. A concern with children would focus on always leaving the filters off and turning them on when a minor requests access, rather than on until an adult requests disabling. ${ }^{13}$

Cornelius [30] defined a traditional public forum as property that has "a principal purpose ... the free exchange of ideas." This would seem to fit the public library's mission rather well. But the Court in $A L A$, in its discussion of the nature of a public library, chooses to focus instead on the "reading" and cultural aspects of the public library. The case of Mainstream Loudoun v. Board of Trustees of Library [4], a federal district court case, concerned the blocking of sexually explicit Web sites. Even though the court there followed the previous courts' conclusions that the public library is a limited forum, it pointed out that once opened up to expressive activity, content restrictions are subject to strict scrutiny. ${ }^{14}$ The $A L A$ Court failed to follow its own previous constitutional analysis and chose to focus instead on the spending power clause.

The $A L A$ Court spent considerable time discussing why a public library's provision of access to the Internet does not create a public forum. This is

13. One should always be mindful, of course, of the level of First Amendment rights that children have.

14. Of course, the effect of United States v. American Library Association is to overrule the decision in Mainstream Loudoun. 
presumably because the provision is emanating from the building where the government is exercising its managerial authority. But several questions beg answers. For example, what about remote access to a library's computers? What about mobile libraries on public streets? What if mobile libraries bring laptops for patrons to access databases, instead of just lending books? Are architectural limitations the defining contours of a public forum? In any case, the Court had the wrong focus in stating that the library does not provide Internet access in order to provide Web publishers with a public forum in which to express themselves [1]. The focus ought to have been on the user, not the producers of the information products. After all, some of the plaintiffs were users. ${ }^{15}$ Similarly, the focus of the library is on book users, not on book publishers.

Even if the Internet is "no more than a technological extension of the book stack," [1, p. 2305] it does multiply the book stack and viewpoints a thousandfold. When patrons are accessing the Internet, they are expressing themselves through, for example, list-servs, chat rooms, e-mail, and other tools. They are also exercising their right to receive information and ideas. ${ }^{16}$ By conditioning receipt of federal funds on public libraries' curtailing of Internet access, Congress is applying the kinds of unconstitutional conditions proscribed in NEA v. Finley [41]. ${ }^{17}$

\section{Conclusion}

The U.S. Supreme Court fails to instruct us on what the characterization of government property has to do with the right to exercise First Amendment freedoms. Apart from Post's theory of managerial authority, I find little theoretical connection between cases involving public forum doctrine and cases involving the regulation of the speech where the context is within

15. A summary of the categories of plaintiffs is instructive: there were nine library associations representing themselves and their members; six public library systems (one including 51 member public libraries); a library board; three patron associations; ten individual library users; and four Web publishers.

16. See Stanley v. Georgia [40]. The "right to receive information and ideas, regardless of their social worth . . . is fundamental to our free society." A fundamental difference between print resources and Internet interactivity seems to be that in the latter you do not have merely readers but speakers as well. Users who chose not to use the filtered computers and did not wish to request that the filters be turned off would not be able to express themselves in any way through the Internet in the library.

17. Unconstitutional conditions refers to the prohibition on government's conditioning receipt of federal funds on the recipient abridging individuals' constitutional rights. It is an open question whether libraries as public entities can rely on the First Amendment rights of their patrons to assert the unconstitutional conditions claim. 
government institutions or where the speakers are recipients of government assistance.

As Post already noted, contemporary public forum doctrine is characterized by "doctrinal incoherence and the absence of underlying constitutional justification" [38, p. 1767] and focuses not on the character of government property but with the nature of managerial authority [p. 1781], which is a retreat from the teachings of Perry [42]. According to Post:

At present, public forum doctrine distinguishes public from nonpublic forums on the basis of a "long tradition" of use for "assembly and debate." The difficulty with this approach is that the Court has been unable to explain why such a tradition should have special constitutional consequences. As reformulated, however, public and nonpublic forums should be distinguished according to whether government authority over a resource is "like" that characteristic of the internal management of a state institution, or instead "like" that characteristic of the governance of the general public. [38, p. 1784]

Post suggests, and I agree, that a resource should be characterized as a public or nonpublic forum based on the social practices within which it is entrenched [38, p. 1800]. Viewed in this vein, the social practices within a library encompass, in addition to the promotion of culture and reading, the facilitation of transmission of ideas, essential aspects of a thriving marketplace of ideas. How, then, can it not be a public forum?

The courts have no business substituting their own opinions for those of the responsible decision maker on the most appropriate method of promoting government interests when analyzing violations of speech in public forums [43]. That libraries were among the plaintiffs opposing CIPA filtering requirements suggests that the Court could not then claim that it was acting on behalf of the libraries, that it was effectively empowering them with collection development decisions.

The Court set us up by casually designating the public library as a limited public forum, thereby allowing it to apply only a reasonableness standard to its analysis of CIPA. If it had gone through the extra step of determining critically what kind of forum a public library is and if it had come to our conclusion that the public library is indeed a public forum, then CIPA, as a content-specific regulation, would not have stood a chance at passing constitutional muster. Certainly, a forum analysis would have affected the constitutionality of the invocation of the spending power clause in this particular case. In any case, while invoking the spending power clause, the $A L A$ Court noted approvingly the insistence that "public funds be spent for the purposes for which they were authorized" [1, p. 2308]. What the Court failed to notice was that the e-rate and LSTA funds were used precisely for the purposes for which they had been provided, namely, to pro- 
vide connectivity. Use of filtering software does not help in connectivity and thus is not a permissible condition under NEA [41].

Comparing the two ALA decisions, the one in the district court [44] and the one by the U.S. Supreme Court, we see that there are striking differences in the levels of analysis that went into the final ruling. ${ }^{18}$ The district court went to great lengths to analyze both the nature of the public library and the nature of Internet access. ${ }^{19}$ It even took the time to decide which level of analysis it should use-the entire library collection or Internet access. The U.S. Supreme Court just assumed the public library was a government property and that the government was merely exercising managerial control when it applied CIPA. The U.S. Supreme Court seems to have ignored even the usual homage to public libraries as designated forums; it merely focused on what it concluded was the nonforum nature of Internet access. In contrast, the district court briefly compared the public library favorably to sidewalks and parks, in the sense that they are generally open to the public to receive speech, and noted that public libraries, like traditional public forums, are funded by taxpayers and do not charge admission [44, pp. 466-67].

Perhaps there should be a new category of public forums, a mixed or dual forum. In the case of the public library, the parts accessible by the public would enjoy the full privileges of a public forum subject to strict scrutiny of speech content regulations and falling under the governance prong, while the staff-only accessible areas would fall under the managerial authority prong. Streets already enjoy this duality: while demonstrators will sometimes walk in the middle of the street, a pedestrian may still be subject to a citation for walking in nondesignated areas in the streets of San Francisco.

\section{REFERENCES}

1. United States v. American Library Association, 539 U.S. 194 (2003); 123 S. Ct. 2297.

2. Neinast v. Board of Trustees of Columbus Metropolitan Library, 346 F.3d 583 (2003).

3. Kreimer v. Bureau of Police for the Town of Morristown, 958 F.2d 1242 (3d Cir. 1992).

4. Mainstream Loudoun v. Board of Trustees of Library, 24 F. Supp. 2d 552 (1998).

5. Habermas, Jurgen. The Structural Transformation of the Public Sphere: An Inquiry into a Category of Bourgeois Society. Cambridge, MA: Harvard University Press, 1989.

6. United States v. Kokinda 497 U.S. 720 (1990).

7. Lloyd Corporation v. Tanner, 407 U.S. 551 (1972).

8. Commonwealth of Massachusetts v. Davis (162 Mass. 510, aff'd, 167 U.S. 43 (1897).

18. This was the district court decision that the U.S. Supreme Court reversed in United States v. American Library Association.

19. Justice Souter, in his dissent in the ALA Court, also looks closely at the nature of libraries and seems to have actually researched this issue. 
9. Kalven, Harry. The Concept of the Public Forum: Cox v. Louisiana, 1965 Sup. Ct. Rev. 1.

10. Hague v. CIO, 307 U.S. 496 (1939).

11. Schneider v. State, 308 U.S. 147 (1939).

12. Jamison v. Texas, 318 U.S. 413 (1943).

13. United States v. Grace, 461 U.S. 171 (1983).

14. Grayned v. Rockford, 408 U.S. 104 (1972).

15. Boos v. Barry, 485 U.S. 312 (1988).

16. Frisby v. Shultz, 487 U.S. 474 (1988).

17. Clark v. Community for Creative Non-Violence, 468 U.S. 288 (1983).

18. Ward v. Rock against Racism, 491 U.S. 781 (1989).

19. Adderly v. Florida, 385 U.S. 39 (1966).

20. Board of Airport Comm'rs of Los Angeles v. Jews for Jesus, Inc., 482 U.S. 569 (1987).

21. Jamison v. St. Louis, 828 F.2d 1280 (1987).

22. Chicago Area Military Project v. Chicago, 508 F.2d 921 (1975).

23. Fernandes v. Limmer, 663 F.2d 619 (1981).

24. U.S. Southwest Africa/Namibia Trade E Cultural Council v. United States, 708 F.2d 760 (1983).

25. International Society for Krishna Consciousness v. Lee, 112 S. Ct. 2701 (1992).

26. Lee v. International Society for Krishna Consciousness, 112 S. Ct. 2709 (1992).

27. Perry Education Association v. Perry Local Educators' Assn., 460 U.S. 37 (1983).

28. Lebron v. National R.R. Passenger Corp. (Amtrak), 69 F.3d 650 (2d Cir. 1995).

29. Greer v. Spock, 424 U.S. 828 (1976).

30. Cornelius v. NAACP Legal Def. Eं Educ. Fund, 473 U.S. 788 (1985).

31. Board of Education, Island Trees Union Free School Dist. No. 26 v. Pico, 457 U.S. 853 (1982).

32. Minarcini v. Strongsville City Sch. Dist., 541 F.2d 577 (6th Cir. 1976).

33. Concerned Women for America Education E Legal Defense Foundation, 699 F. Supp. 95 (1988).

34. Willis v. Town of Marshall, 293 F. Supp. 2d 608 (2003).

35. Stone, Geoffrey R. Fora Americana: Speech in Public Places, 1974 Sup. Ct. Rev. 233.

36. Regan v. Taxation with Representation of Wash., 461 U.S. 540 (1983).

37. FCC v. League of Women Voters, 468 U.S. 364 (1984).

38. Post, Robert. Between Governance and Management: The History and Theory of the Public Forum, 34 UCLA L. Rev. 1713-1824 (1987).

39. United States v. Playboy Entertainment Group, Inc., 529 U.S. 803 (2000).

40. Stanley v. Georgia, 394 U.S. 557 (1969).

41. NEA v. Finley, 524 U.S. 569 (1998).

42. Perry Education Association v. Perry Local Educators' Ass'n, 460 U.S. 37 (1983).

43. Housing Works, Inc. v. Kerik, 283 F.3d 471 (2002).

44. American Library Association v. United States, 201 F. Supp. 2d 401 (2002). 